\title{
A new species of Microcancilla from the southwestern Atlantic and notes on Microcancilla brasiliensis comb. nov. (Gastropoda, Cancellariidae)
}

\author{
Leonardo Santos de Souza ${ }^{1,3}$; Alexandre Dias Pimenta ${ }^{1,4}$ \& Cintia Miyaji ${ }^{2,5}$ \\ 1 Universidade Federal do Rio de Janeiro (UFRJ), Museu Nacional (MN), Departamento de Invertebrados, Laboratório de Malacologia. \\ Rio de Janeiro, RJ, Brasil. \\ 2 Paiche Consultoria. Santos, SP, Brasil. \\ ${ }^{3}$ ORCID: http://orcid.org/0000-0002-8242-010X. E-mail: leosouza2301@gmail.com (corresponding author) \\ ${ }^{4}$ ORCID: http://orcid.org/0000-0001-7001-5820. E-mail: alexpim@mn.ufrj.br \\ ${ }^{5}$ ORCID: http://orcid.org/0000-0003-3554-9776. E-mail: cintiamiyaji@gmail.com
}

\begin{abstract}
Microcancilla phoenix sp. nov., collected from the Southeast and South coast of Brazil represents the southernmost record of the genus in the Atlantic 0 cean. The new species differs from the other congeners of the Atlantic mainly by the presence of microscopic pustules covering the whole shell and by dimensions of the protoconch. "Axelella brasiliensis"Verhecken, 1991, known from the Northeast to South coast of Brazil, is transferred to Microcancilla based on a similar sculpture of microscopic pustules on the protoconch and on other features of the teleoconch discussed in the present study.
\end{abstract}

Keywords. Volutoidea; Admetinae; Microsveltia; Pseudobabylonella; Zeadmete; Taxonomy; Shell morphology; South Atlantic.

\section{INTRODUCTION}

Cancellariidae Forbes \& Hanley, 1851 comprises marine gastropods that inhabit several types of soft bottoms, characterized by small to medium sized, fusiform to ovate shells with gradate to scalariform shapes. They are dextrally coiled and commonly bear axial and spiral sculptures that produce a cancellate or reticulate surface (Harasewych \& Petit, 1998; Petit \& Harasewych, 2005). Cancellariids are found from Arctic to Antarctic seas and in a great bathymetric range, including shallow waters to the deep sea (Harasewych \& Petit, 2014).

Cancellariidae is currently classified in the superfamily Volutoidea Rafinesque, 1815 together with Volutidae Rafinesque, 1815 (Bouchet et al., 2017). The family includes about 350 valid extant species (MolluscaBase, 2019) distributed into 67 genera (extant and fossils), and to date three subfamilies are recognized: Admetinae Troschel, 1865, Cancellariinae Forbes \& Hanley, 1851 and Plesiotritoninae Beu \& Maxwell, 1987 (Bouchet et al., 2017). Admetinae usually comprise species with smaller, thinner shells, which lack an umbilicus and columellar folds; Cancellariinae usually comprise species with heavy shells, strongly to weakly shouldered, with stronger reticulate or cancellate sculpture, weak varices, two to three columellar folds, and presence or absence of an umbilicus; Plesiotritoninae usually comprise species with a high spire presenting varices and non-collabral axial sculpture (Harasewych \& Petit, 1998). However, some genera have a doubtful position and are not assigned to any of these subfamilies by MolluscaBase (2019).

Microcancilla Dall, 1924 is currently considered a member of Admetinae (MolluscaBase, 2018). This genus was erected without a diagnosis and only including Microcancilla microscopica (Dall, 1889). More recently, Barros \& Petit (2007) described Microcancilla jonasi despite uncertainties about the generic classification. To date Microcancilla only encompasses Atlantic species, but Barros \& Petit (2007) stated that there are some species from the central Pacific clearly attributable to this genus. Microcancilla microscopica is known from the Northwest Atlantic (Dall, 1889 ) and $M$. jonasi is known only from the continental slope off Pernambuco, Northeast Brazil (Barros \& Petit, 2007).

In this paper, we describe a new species of Microcancilla from the Southeast and South coast of Brazil. Reassessment of material of "Axelella 
brasiliensis" Verhecken, 1991 also suggests the classification of this species in Microcancilla.

\section{MATERIAL AND METHODS}

Specimens examined herein were collected mainly by two projects: 1) "Programa de Avaliação do Potencial Sustentável deRecursosVivos daZonaEconômicaExclusiva" [Program of Evaluation of the Sustainable Potential of Living Resources in the Economic Exclusive Zone] (REVIZEE Sul), which sampled the Southeast and South coast of Brazil, between December 1997 and April 1998, aboard Research Vessel (RV) Prof. W. Besnard; 2) "Importância e caracterização da quebra da plataforma para recursos vivos e não vivos - Programa de Apoio ao Desenvolvimento Tecnológico e Científico" [Importance and characterization of the continental shelf break for living and non-living resources - Support Program for Technological and Scientific Development] (PADCT), between November 1997 and January 1998, aboard RV Prof. W. Besnard.

Table 1 presents data on the collecting stations where the present material was found. Specimens examined consist only of empty shells. The number of examined specimens is indicated in brackets in the material examined section. Most of the material studied here was housed in the "Museu Nacional, Universidade Federal do Rio de Janeiro". Due to the fire of September 2018 (Zamudio et al., 2018), most of the vouchers were destroyed and in these cases the catalog numbers are followed by a dagger ( $\dagger$ ).

Shells were studied using a Scanning Electron Microscope (SEM) JEOL JSM-6390LV at the "Centro de Microscopia Eletrônica, Departamento de Invertebrados, Museu Nacional, Universidade Federal do Rio de Janeiro". Photographs of shells were taken using an AxioCam ICc5 camera coupled to a Zeiss Discovery.V20 stereomicroscope and automated stacking.

Abbreviations for measurements: $A L=$ aperture length; $A W=$ aperture width; $B W L$ = body whorl length;

Table 1. Sampling stations of the REVIZEE and PADCT surveys cited in the present study.

\begin{tabular}{|c|c|c|c|c|}
\hline Station (stn.) & Latitude (S) & Longitude (W) & Depth (m) & Date \\
\hline PADCT stn. 6541 & $23^{\circ} 35^{\prime} 49^{\prime \prime}$ & $41^{\circ} 42^{\prime} 25^{\prime \prime}$ & 143 & xi.1997-i.1998 \\
\hline PADCT stn. 6553 & $23^{\circ} 49^{\prime} 04^{\prime \prime}$ & $42^{\circ} 46^{\prime} 48^{\prime \prime}$ & 225 & xi.1997-i.1998 \\
\hline PADCT stn. 6579 & $24^{\circ} 42^{\prime} 18^{\prime \prime}$ & $45^{\circ} 18^{\prime} 49^{\prime \prime}$ & 84 & xi.1997-i.1998 \\
\hline PADCT stn. 6595 & $26^{\circ} 23^{\prime} 32^{\prime \prime}$ & $46^{\circ} 39^{\prime} 29^{\prime \prime}$ & 175 & xi.1997-i.1998 \\
\hline PADCT stn. 6601 & $27^{\circ} 18^{\prime} 16^{\prime \prime}$ & $47^{\circ} 08^{\prime} 46^{\prime \prime}$ & 228 & xi.1997-i.1998 \\
\hline PADCT stn. 6608 & $28^{\circ} 00^{\prime} 03^{\prime \prime}$ & $46^{\circ} 59^{\prime} 40^{\prime \prime}$ & 490 & xi.1997-i.1998 \\
\hline PADCT stn. 6611 & $28^{\circ} 24^{\prime} 22^{\prime \prime}$ & $47^{\circ} 21^{\prime} 38^{\prime \prime}$ & 195 & xi.1997-i.1998 \\
\hline PADCT stn. 6627 & $23^{\circ} 57^{\prime} 59^{\prime \prime}$ & $43^{\circ} 52^{\prime} 33^{\prime \prime}$ & 133 & xi.1997-i.1998 \\
\hline PADCT stn. 6635 & $27^{\circ} 10^{\prime} 22^{\prime \prime}$ & $47^{\circ} 27^{\prime} 32^{\prime \prime}$ & 129 & xi.1997-i.1998 \\
\hline REVIZEE-Sul stn. 6651 & $25^{\circ} 53^{\prime} 34^{\prime \prime}$ & $45^{\circ} 42^{\prime} 07^{\prime \prime}$ & 256 & 15.xii.1997 \\
\hline REVIZEE-Sul stn. 6652 & $25^{\circ} 51^{\prime} 02^{\prime \prime}$ & $45^{\circ} 47^{\prime} 18^{\prime \prime}$ & 206 & 15.xii.1997 \\
\hline REVIZEE-Sul stn. 6658 & $25^{\circ} 11^{\prime} 40^{\prime \prime}$ & $47^{\circ} 08^{\prime} 05^{\prime \prime}$ & 50 & 16.xii.1997 \\
\hline REVIZEE-Sul stn. 6660 & $24^{\circ} 17^{\prime} 40^{\prime \prime}$ & $43^{\circ} 48^{\prime} 11^{\prime \prime}$ & 314 & 09.i.1998 \\
\hline REVIZEE-Sul stn. 6669 & $24^{\circ} 07^{\prime} 20^{\prime \prime}$ & $44^{\circ} 42^{\prime} 08^{\prime \prime}$ & 101 & 11.i.1998 \\
\hline REVIZEE-Sul stn. 6680 & $25^{\circ} 15^{\prime} 03^{\prime \prime}$ & $44^{\circ} 52^{\prime} 51^{\prime \prime}$ & 258 & 12.i.1998 \\
\hline
\end{tabular}

$\mathrm{SL}=$ shell length; $\mathrm{SW}=$ shell width. Protoconch whorl countings follows Verhecken (2007).

Acronyms of collections: $M N H N-I M=$ Muséum national d'Histoire naturelle, Paris, France; MNRJ = Museu Nacional, Universidade Federal do Rio de Janeiro, Rio de Janeiro, Brazil.

\section{Taxonomy}

\section{Genus Microcancilla Dall, 1924}

Type species: Admete microscopica (Dall, 1889) [= Cancellaria microscopica Dall, 1889], by original designation. Recent, Caribbean.

\section{Microcancilla phoenix sp. nov. http://zoobank.org/60489198-E5B0-4CE3-968D-B66EEB5DB937} (Figs. 1A-H, 2A-F)

Axelella brasiliensis - Wiggers \& Veitenheimer-Mendes (2003: 58, fig. 15); Forcelli \& Narosky (2015: pl. 5, fig. 1) (non Verhecken, 1991).

Type material: Holotype MNRJ 60299. Paratypes: BRAZIL: São Paulo: PADCT stn. 6627: MNRJ 28192† [1]; REVIZEE Sul stn. 6658: MNRJ 60302 [1]; Paraná: REVIZEESul stn. 6652: MNRJ 23200† [54], MNRJ 28183† [1].

Type locality: BRAZIL: Santa Catarina: PADCT stn. 6595 $\left(26^{\circ} 23^{\prime} 32^{\prime \prime} \mathrm{S}, 46^{\circ} 39^{\prime} 29^{\prime \prime} \mathrm{W}, 175 \mathrm{~m}\right)$, coll. RV Prof. W. Besnard, xi.1997-i.1998.

Additional material examined: BRAZIL: from type locality: MNRJ 28191† [1], MNRJ† [9]; Rio de Janeiro: PADCT stn. 6541: MNRJ† [2]; PADCT stn. 6553: MNRJ 28188† [1]; PADCT stn. 6627: MNRJ† [2]; São Paulo: REVIZEE-Sul stn. 6669: MNRJ 28189† [3]; REVIZEE-Sul stn. 6660: MNRJ† [1]; PADCT stn. 6579: MNRJ 28184† [3]; REVIZEE-Sul stn. 6680: MNRJ† [1]; Paraná: REVIZEE-Sul stn. 6651: MNRJ† [2]; Santa Catarina: PADCT stn. 6635: MNRJ 28187† [4]; PADCT stn. 6601: MNRJ 28186† [4]; PADCT stn. 6608: MNRJ† [8]; PADCT stn. 6611: MNRJ† [1].

Description: Shell conical, spire short, whitish, reaching $4.25 \mathrm{~mm}$ long and $2.41 \mathrm{~mm}$ wide. Protoconch paucispiral, globose, covered by microscopic pustules, 1.25 whorls, $600 \mu \mathrm{m}$ long, $700 \mu \mathrm{m}$ wide, transition distinguishable by emergence of axial sculpture of teleoconch. Teleoconch with 3.0 slightly convex whorls, reticulated, shouldered; suture well-demarcated, with small, almost flat subsutural region ornamented by axial cords, nodulated at margin. Last whorl occupying $70 \%$ of whole shell length, with six spiral cords between sutures and about 20 axial cords since outer lip. Base slightly sinuous, with three to four spiral cords. Aperture wide, almost elliptical, rounded posteriorly, more constricted anteriorly at slightly elongated siphonal canal. Outer lip thin, prosocline. 

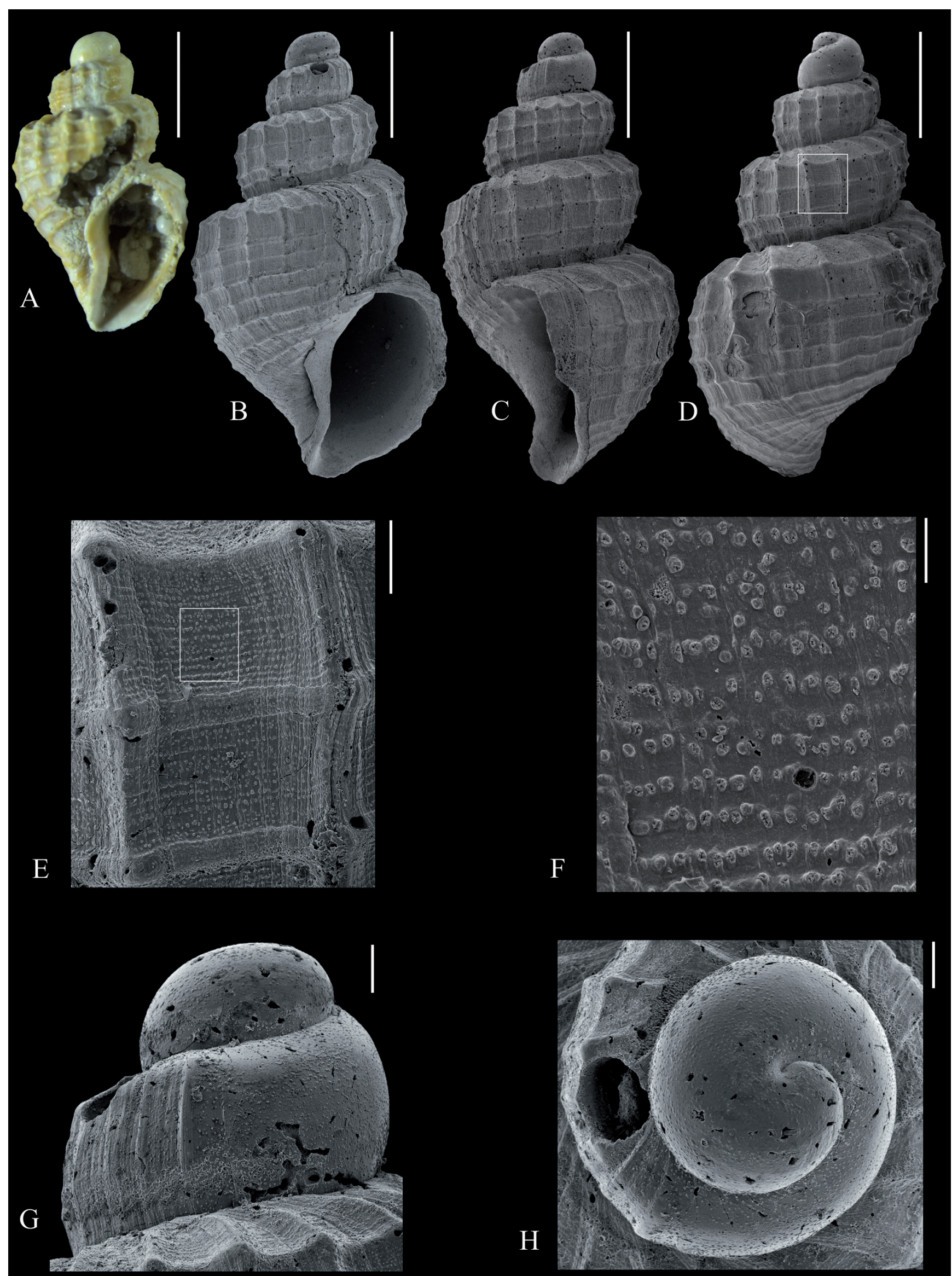

Figure 1. Microcancilla phoenix sp. nov. (A) Holotype, MNRJ 60299 (2.85 mm long). (B-H) Paratype, MNRJ 28183 (4.25 mm long). (A-B) entire shell in ventral view. (C) same, lateral view. (D) same, dorsal view, white square enlarged in E. (E) Detail of teleoconch sculpture, white square enlarged in F. (F) Detail of microscopic pustules covering the shell. (G) Protoconch in frontal view. (H) Protoconch in apical view. Scale bars: $A-D=1 \mathrm{~mm} ; E, G, H=100 \mu \mathrm{m} ; F=20 \mu m$. 
Inner lip sinuous, reflected, slightly folded about middle; presence of very minute umbilical chink behind inner lip.

Measurements: Holotype: whorls $=3.0 ; \mathrm{SL}=2.85 \mathrm{~mm}$; $B W L=2.24 \mathrm{~mm} ; A L=1.42 \mathrm{~mm} ; \mathrm{SW}=1.68 \mathrm{~mm}$; $\mathrm{AW}=0.98 \mathrm{~mm}$. Paratype MNRJ 28183: Whorls = 4.25; $\mathrm{SL}=4.20 \mathrm{~mm} ; B W L=3.01 \mathrm{~mm} ; A L=1.81 \mathrm{~mm}$; $\mathrm{SW}=2.41 \mathrm{~mm} ; \mathrm{AW}=1.31 \mathrm{~mm}$.

Etymology: phoenix (Latin) refers to a fabled bird symbolic of resurrection and immortality; the epithet is named in honor of the "Museu Nacional". Epithet as a noun in apposition.
Geographic distribution: BRAZIL: from Rio de Janeiro (this study) to Rio Grande do Sul (Wiggers \& VeitenheimerMendes, 2003; Forcelli \& Narosky, 2015).

\section{Bathymetric range: From $50 \mathrm{~m}$ to $490 \mathrm{~m}$.}

Remarks: The previously selected type series of M. phoenix sp. nov., including the holotype, was destroyed by the fire of "Museu Nacional". An additional shell was obtained later; in spite of it being a younger and partially broken shell, we choose a preserved specimen as the name-bearing type of $M$. phoenix (Fig. 1A).

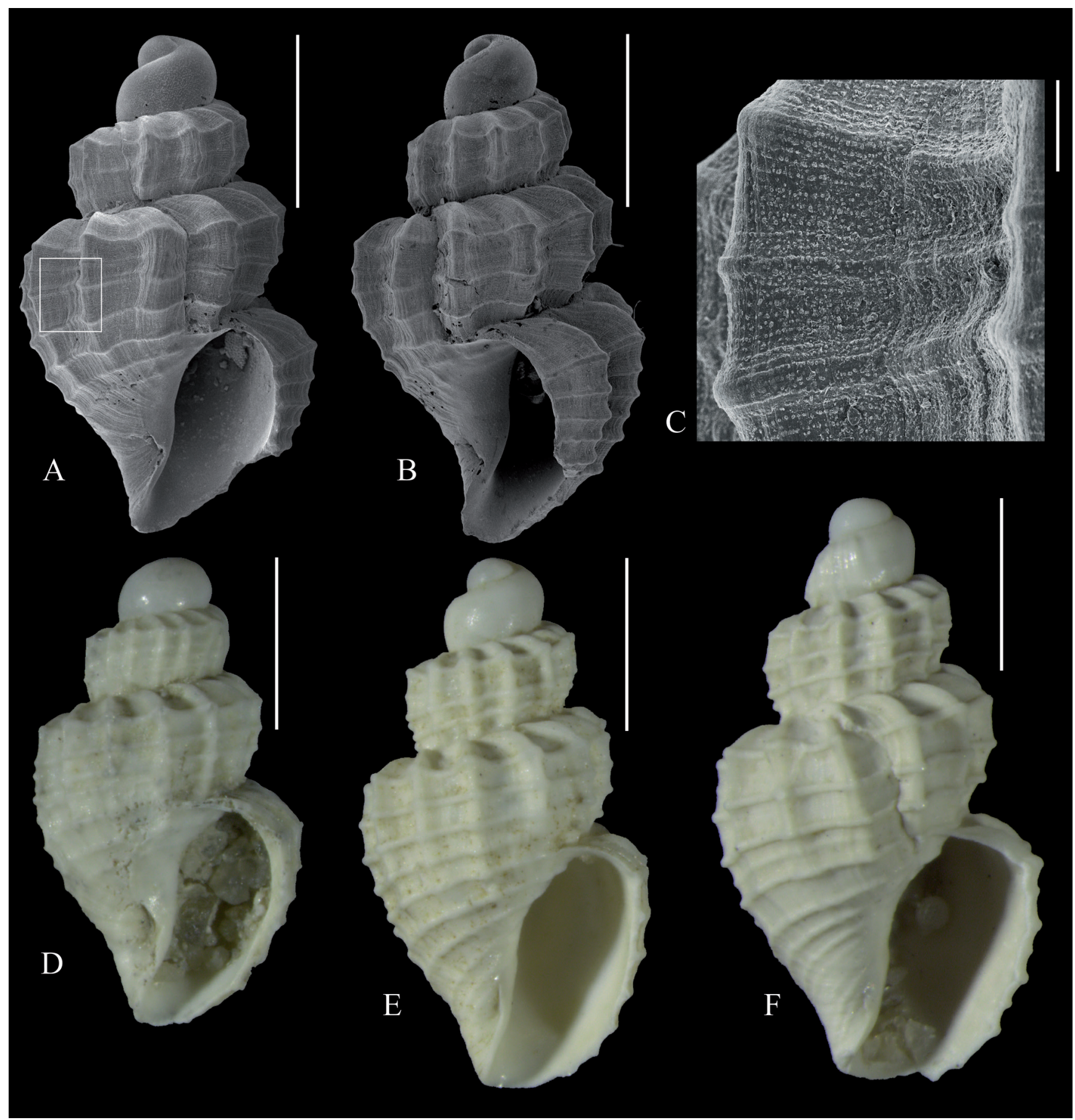

Figure 2. Microcancilla phoenix sp. nov. (A-C) MNRJ 28191 (2.94 mm long). (D-E) MNRJ 28189 (2.72 mm, $3.07 \mathrm{~mm}$ and 3.39 mm, respectively). (A, B, D-F) Entire shell in ventral view, white square in $A$ enlarged in C. (B) same, lateral view. (C) Detail of teleoconch sculpture. Scale bars: $A, B, D-F=1 \mathrm{~mm} ; C=100 \mu \mathrm{m}$. 
Some shells of $M$. phoenix (Figs. 1A-D) have axial cords slightly thinner than others (Figs. 2A-C, E, F). A small gradient can be observed in Figs. 2D-F. The two types of sculpture occur in specimens from the same locality (Figs. 2D-F) and this may be due to intraspecific variability. Despite these differences, both forms have the same number of protoconch whorls (1.25), with a mean height of $590 \mu \mathrm{m}(n=6)$. The dimensions of the teleoconch are proportionally similar.

Microcancilla microscopica (Dall, 1889), known from Florida, USA, and western Caribbean, has a smaller protoconch (Lectotype USNM 82977, designated by Barros \& Petit (2007: 99), 0.75 whorls, $560 \mu \mathrm{m}$ wide vs. Holotype of M. phoenix, 1.25 whorls, $700 \mu \mathrm{m}$ wide), wider parietal region, and a shorter siphonal canal (Barros \& Petit, 2007: figs. 9-11).

Microcancilla jonasi Barros \& Petit, 2007, known from Northeast Brazil, differs by the very faint spiral sculpture with stronger axial ribs and by the flatter and narrower subsutural region resembling a crown as a result of the axial sculpture (Barros \& Petit, 2007: figs. 1-8).

Brocchinia pustulosa Verhecken, 1991 has a similar number of protoconch whorls (1.25), but the protoconch is wider $(800 \mu \mathrm{m}$ high and $900 \mu \mathrm{m}$ wide vs. Holotype of M. phoenix, $600 \mu \mathrm{m}$ high and $700 \mu \mathrm{m}$ wide) (seeVerhecken, 1991: figs. 3-4, for data of B. pustulosa). Furthermore, $B$. pustulosa is larger in general, reaching $10.7 \mathrm{~mm}$ long, more twice the length of $M$. phoenix in shells with a similar number of whorls, and also has a stronger nodulation in the teleoconch (Verhecken, 1991: figs. 1-2).

\section{Microcancilla brasiliensis (Verhecken, 1991) comb. nov.} (Figs. 3A-G)

Axelella brasiliensis Verhecken, 1991: 549, figs. 5-6.

Axelella brasiliensis - Rios, 1994: 155, pl. 51, fig. 684 [reproduced from original illustration]; Miyaji, 2004: 79; Veitenheimer-Mendes et al., 2004: 97; Petit \& Harasewych, 2005: 32 [annotated list]; Rios, 2009: 298, fig. 751 [reproduced from original illustration].

Pseudobabylonella brasiliensis - Petit, 2012: 4.

Type material: Holotype MNHN-IM-2000-2128.

Type locality: BRAZIL: Espírito Santo: MD-55 stn. SY 74 (18 $\left.58^{\prime} \mathrm{S}, 37^{\circ} 49^{\prime} \mathrm{W}, 682 \mathrm{~m}\right)$, coll. RV Marion Dufresne (P. Bouchet, J. Leal and B. Métivier), 27.v.1987.

Material examined: BRAZIL: São Paulo: Santos

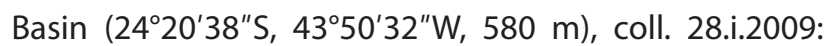
MNRJ 28851† [1]; Paraná: REVIZEE-Sul stn. 6652: MNRJ $28182+[1]$.

Measurements: MNRJ 28851: Whorls = 4.75; $\mathrm{SL}=4.54$; $B W L=2.97 \mathrm{~mm} ; A L=1.84 \mathrm{~mm} ; \mathrm{SW}=2.47 \mathrm{~mm}$; $\mathrm{AW}=1.17 \mathrm{~mm}$.

Geographic distribution: BRAZIL: Pernambuco to Paraná (Verhecken, 1991, 2002; Miyaji, 2004; Veitenheimer-Mendes et al., 2004).
Bathymetric range: From $206 \mathrm{~m}$ to $637 \mathrm{~m}$.

Remarks: Petit (2012) included this species in Pseudobabylonella Brunetti, Bella, Forli \& Vecchi, 2009, possibly by the statement of Brunetti et al. (2009: 66): "The new genus [Pseubabylonella], which is characterized mainly by the sculpture of the protoconch, comprise species previously included in Axelella and Babylonella" [translated from Italian]. Brunetti et al. (2009) described a protoconch with numerous well-developed spiral and axial cords of sinuous outline.

The holotype of Microcancilla brasiliensis comb. nov. has an eroded protoconch (Verhecken, 1991: fig. 6) which precludes the analysis of microsculpture. Verhecken (2002) reported new records of $M$. brasiliensis (as "Axelella brasiliensis") and figured a more preserved protoconch, but the illustrations do not allow for an assessment of the microsculpture and no sculpture was described.

The additional material $M$. brasiliensis studied here shows microscopic pustules arranged fairly in spiral lines and at irregular intervals (Figs. 3E, G) on the protoconch, which differ from the sculpture pattern of Pseudobabylonella. The protoconch-teleoconch transition in $M$. brasiliensis is not clearly marked like in Pseudobabylonella, in which the reticulated teleoconch sculpture starts as faint axial ribs (Fig. 3E). Thus, the protoconch morphology of $M$. brasiliensis is more similar to $M$. phoenix, and we decide to include this species in Microcancilla rather than in Pseudobabylonella despite uncertainties.

Microcancilla phoenix (Figs. 1A-H, 2A-F) has microscopic pustules covering the whole shell, not restricted to the protoconch like $M$. brasiliensis. Additionally, M. phoenix has a more rounded aperture and subsutural region (Figs. 1A, B), while $M$. brasiliensis has a more triangular aperture and a flatter shoulder (Fig. 3A).

Microcancilla microscopica and M. jonasi also differ by the more rounded aperture and by the wider parietal region (Barros \& Petit, 2007: figs. 1-5, 9).

Miyaji (2004) and Veitenheimer-Mendes et al. (2004) reported M. brasiliensis (as "Axelella brasiliensis") from South Brazil in an annotated list of species without illustrations. The records reported by those authors are the southernmost records of $M$. brasiliensis $\left(\sim 26^{\circ} \mathrm{S}\right)$ and one of them is the shallowest record of the species at $206 \mathrm{~m}$ (MNRJ 28182).

\section{DISCUSSION}

The species treated in this study are tentatively placed in Microcancilla by the similarity of the general shell shape, size, and absence of distinct columellar folds like in M. microscopica. Despite this, M. phoenix sp. nov., and $M$. brasiliensis comb. nov. have a microscuIpture of pustules on the protoconch and/or teleoconch (Figs. 1E-H, 2C, 3E, G), a feature not described in M. microscopica and in $M$. jonasi under SEM examination by Barros \& Petit (2007). 
Another possible generic placement for the species treated herein is Zeadmete Finlay, 1926, discussed by Petit \& Harasewych (2000), Bouchet \& Petit (2008) and
Verhecken (2011). Zeadmete also has weak, almost obsolete folds in the inner lip (Bouchet \& Petit, 2008: 2), but there is no mention about microscopic pustules covering
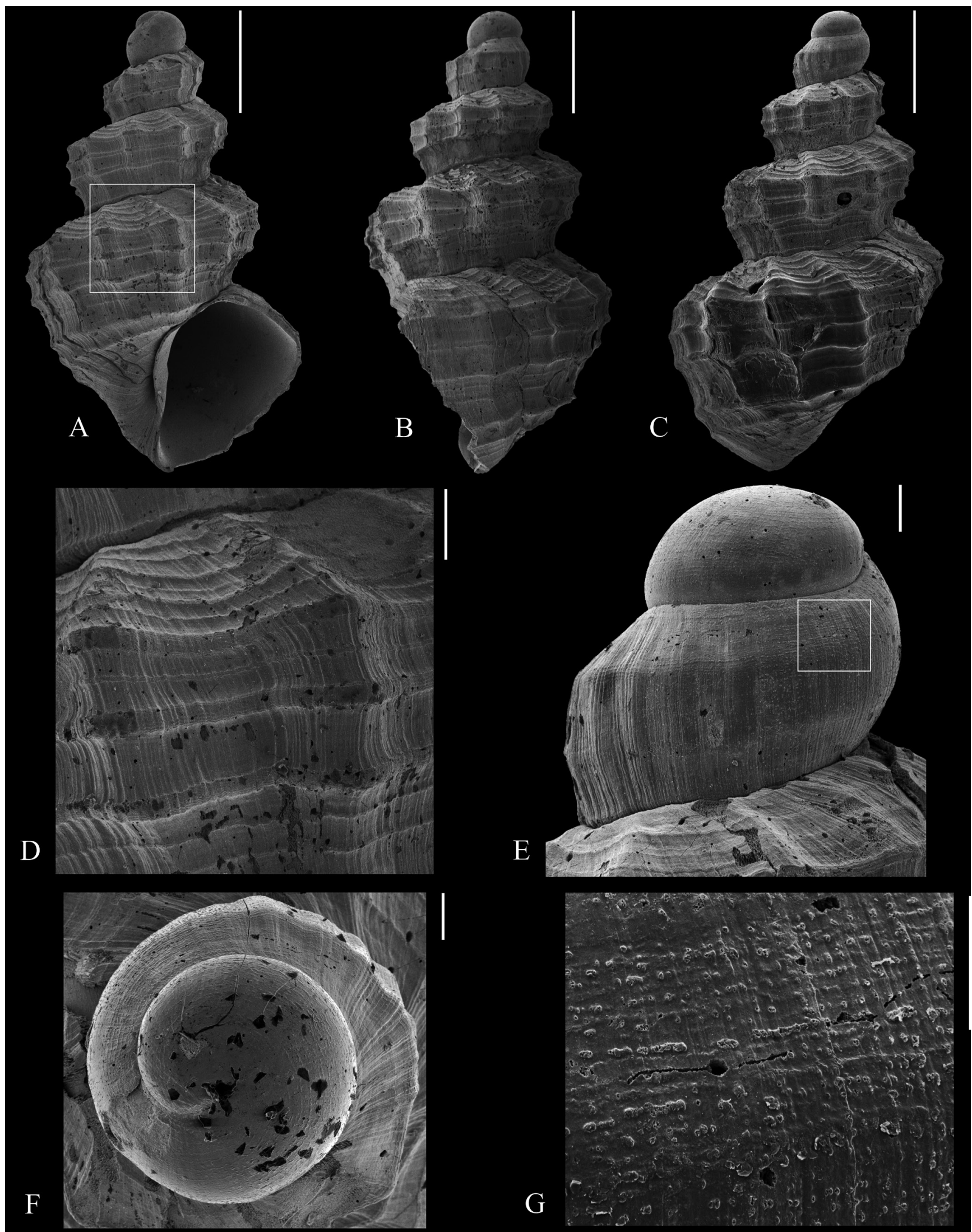

Figure 3. Microcancilla braziliensis comb. nov. (A-G) MNRJ 28182 (4.49 mm long). (A) Entire shell in ventral view, white square enlarged in D. (B) same, lateral view. (C) same, dorsal view. (D) Detail of teleoconch sculpture. (E) Protoconch in frontal view, white square enlarged in G. (F) same, apical view. (G) Detail of protoconch sculpture. Scale bars: $A-C=1 \mathrm{~mm} ; \mathrm{D}=200 \mu \mathrm{m} ; \mathrm{E}-\mathrm{F}=100 \mu \mathrm{m} ; \mathrm{G}=50 \mu \mathrm{m}$. 
the protoconch and/or teleoconch. Zeadmete atlantica Petit, Campbell \& Campbell, 2010 is the only species of the genus reported for the Atlantic Ocean.

Cancellicula Tabanelli, 2008 was erected to comprise fossil species of the Pliocene (Tabanelli, 2008) and shares some conchological features with Microcancilla, such as the general shape of the shell and the absence of columellar folds (Brunetti et al., 2009). The fossil species assigned to this genus, Cancellicula dregeri (Hoernes \& Auinger, 1890) (type species) and Cancellicula profunda (Tabanelli, 1985), differ from Microcancilla by having a multispiral protoconch, sculptured by a weak spiral cord and thin orthocline axial ribs, and by the flatter shoulder of the teleoconch whorls (Brunetti et al., 2009). More recently, Verhecken (2011) included Admete aethiopica Thiele, 1925, an extant species from the Indian and Pacific Oceans, in Cancellicula. The protoconch of Cancellicula aethiopica (Thiele, 1925) is more similar to the protoconch of Microcancilla, which is paucispiral and presents a microsculpture of small pustules arranged spirally (Verhecken, 2011: pl. 15, fig. 3A-B). Despite proposing the classification of the latter species in Cancellicula, Verhecken (2011: 40) stated that "the relation between Microcancilla and Cancellicula may need further study".

The genus Microsveltia Iredale, 1925 also includes species with size and shape similar to Microcancilla, but the type species (Microsveltia recessa Iredale, 1925) and most species included in the genus have two columellar folds and lack any microsculpture, except for Microsveltia tupasi Verhecken, 2011 (Verhecken, 2011). The shell of M. tupasi is completely covered by a microsculpture of arrowheads and T-characters pointing adaperturally, arranged in spiral and axial rows (Verhecken, 2011: pl. 11, fig. 3, pl. 15, figs. 2A-B). Moreover, due to the species having no columellar fold and Verhecken (2011) was unsure about the generic and even familial placement of $M$. tupasi.

The generic classification of small cancellariids (less than $10 \mathrm{~mm}$ ), especially for deep-sea species (Maxwell, 1992; Barros \& Petit, 2007) is still obscure. Provisional generic classifications often occur in these groups and a more comprehensive study about these and other similar genera of Cancellariidae is still necessary to substantiate an accurate classification of these species.

The present study expands the geographic distribution of Microcancilla southwards to the Southwest Atlantic ( 32 $\left.{ }^{\circ} \mathrm{S}\right)$ (Fig. 4). Microcancilla brasiliensis and M. phoenix show a wider latitudinal range (Fig. 4) in comparison to their congeners. The distribution of this genus remains restricted to the Atlantic Ocean (Fig. 4).

\section{ACKNOWLEDGMENTS}

We are grateful to "Ministério do Meio Ambiente" and "Conselho Nacional de Desenvolvimento Científico e Tecnológico" (CNPq) for the financial support of the projects REVIZEE Sul and PADCT; to C. Messias (MNRJ) for SEM micrographs. We are deeply grateful to A. Verhecken (RBINS) for discussions on an early version of this manuscript and for sharing literature. Also, we wish

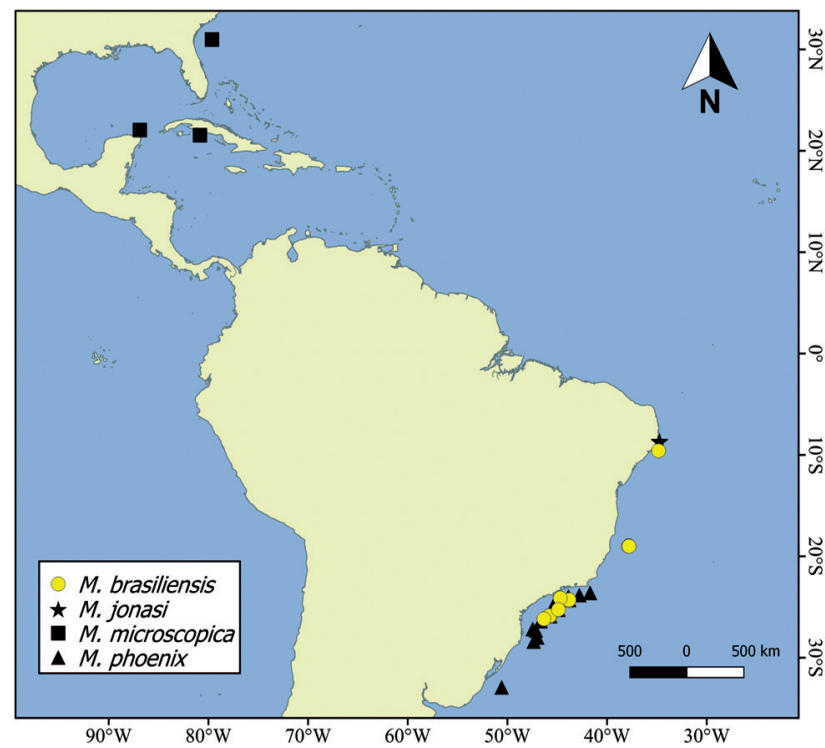

Figure 4. Known records of Microcancilla species based on the literature and on the material examined in the present study.

to thanks the anonymous referees and the editors $C$. Lamas and $\mathrm{L}$. Simone for the revision of the manuscript. The senior author also thanks CNPq and "Conselho de Aperfeiçoamento de Ensino Superior" (CAPES) for a doctoral scholarship (CNPq/MCTI/FAP/PROTAX \#001/2015).

\section{AUTHORS' CONTRIBUTIONS}

L.S.S. and C.M. sorted the samples. A.D.P. provided the resources. All authors actively participated in the conceptualization, investigation, description of specimens, results and discussion. L.S.S. produced the original draft and all authors reviewed and approved the final version of the paper.

\section{REFERENCES}

Barros, J.C.N. \& Petit, R.E. 2007. A new species of Microcancilla (Gastropoda: Cancellariidae) from the continental slope off northeastern Brazil. The Nautilus, 121(2): 95-98.

Bouchet, P. \& Petit, R.E. 2008. New species and new records of southwest Pacific Cancellariidae (Gastropoda). The Nautilus, 122(1): 1-18.

Bouchet, P.; Rocroi, J.-P.; Hausdorf, B.; Kaim, A.; Kano, Y.; Nützel, A.; Parkhaev, P.; Schrödl, M. \& Strong, E.E. 2017. Revised classification, nomenclator and typification of gastropod and monoplacophoran families. Malacologia, 61(1-2): 1-526. D0I

Brunetti, M.M.; Bella, G.D.; Forli, M. \& Vecchi, G. 2009. La famiglia Cancellariidae Forbes \& Hanley, 1851 (Gastropoda) nel Plio-Pleistocene italiano: i generi Bonellitia, Pseudobabylonella n. gen., Admete e Cancellicula Tabanelli, 2008, con descrizione di tre nuove specie. Bollettino Malacologico, 45: 55-81.

Dall, W.H. 1889. Reports on the results of dredgings, under the supervision of Alexander Agassiz, in the Gulf of Mexico (1877-78) and in the Caribbean Sea (1879-80), by the U.S. Coast Survey Steamer 'Blake'. Bulletin of the Museum of Comparative Zoology, 18: 1-492, pls. 10-40.

Forcelli, D. \& Narosky, T. 2015. Moluscos marinos de Argentina, Uruguay y Brasil - Uruguayan Seashells. Buenos Aires, Vázquez Mazzini. 
Harasewych, M.G. \& Petit, R.E. 1998. Superfamily Cancellarioidea. In: Beesley, P.L.; Ross, G.J.B. \& Wells, A. Mollusca: The Southern Synthesis, Fauna of Australia. Vol. 5. Part B. Melbourne, CSIRO Publishing. p. 845-846.

Harasewych, M.G. \& Petit, R.E. 2014. Cancellaria (Cancellaria) coltrorum, a new species of Cancellariidae (Gastropoda: Neogastropoda) from Brazil. Proceedings of the Biological Society of Washington, 127(2): 400-405. D0I

Maxwell, P.A. 1992. Eocene Mollusca from the vicinity of McCulloch's Bridge, Waihao River, South Canterbury, New Zealand. Paleontological Bulletin, 65: $1-280$

Miyaji, C. 2004. Classe Gastropoda. In: Amaral, A.C.Z. \& Rossi-Wongtschowski, C.L.B. Biodiversidade bentônica da região Sudeste-Sul do Brasil, plataforma externa e talude superior. São Paulo, Instituto Oceanográfico, USP. p. 78-87.

MolluscaBase. 2018. Microcancilla Dall, 1924. Available: http://molluscabase. org/aphia.php?p=taxdetails\&id=456466. Access: 24/12/2019.

MolluscaBase.2019.MolluscaBase.CancellariidaeForbes\&Hanley, 1851.Available: http://www.marinespecies.org/aphia.php? $\mathrm{p}=$ taxdetails\&id $=13600$. Access: 24/12/2019.

Petit, R.E. 2012. A critique of, and errata for, Recent Cancellariidae by Jens Hemmen, 2007. Conchologia Ingrata, 9: 1-8.

Petit, R.E. \& Harasewych, M.G. 2000. Additions to the cancellariid (Mollusca: Neogastropoda) fauna of South Africa. Proceedings of the Biological Society of Washington, 113(1): 145-154.

Petit, R.E. \& Harasewych, M.G. 2005. Catalogue of the superfamily Cancellarioidea Forbes and Hanley, 1851 (Gastropoda: Prosobranchia). $2^{\text {nd }}$ edition. Zootaxa, 1102(1): 1-161.

Rios, E.C. 1994. Seashells of Brazil. $2^{\text {nd }}$ edition. Rio Grande, Editora da Fundação Universidade do Rio Grande.

Rios, E.C. 2009. Compendium of Brazilian sea shells. Rio Grande, Evangraf.

Tabanelli, C. 2008. Associazioni di Paleocomunitá batiali a molluschi bentonici nem Pliocene dela Romagna. Quaderno diStudie Notizie di Storia Naturale dela Romagna, 26: 1-80.
Veitenheimer-Mendes, I.L.; Wiggers, F. \& Pimpão, D.M. 2004. Classes Gastropoda e Bivalvia. Região Sul. In: Amaral, A.C.Z. \& RossiWongtschowski, C.L.B. Biodiversidade bentônica da região Sudeste-Sul do Brasil, plataforma externa e talude superior. São Paulo, Instituto Oceanográfico, USP. p. 97-110.

Verhecken, A. 1991. Description of two new species of bathyal Cancellariidae (Mollusca, Gastropoda) from off Brazil. Bulletin Museum National d'Histoire Naturelle, 4e ser., 12, section A, (3-4): 547-553.

Verhecken, A. 2002. Atlantic bathyal Cancellariidae (Neogastropoda: (ancellarioidea): additional data, and description of a new species. Journal of Conchology, 37(5): 505-514.

Verhecken, A. 2007. Revision of the Cancellariidae (Mollusca, Neogastropoda, Cancellarioidea) of the eastern Atlantic $\left(40^{\circ} \mathrm{N}-40^{\circ} \mathrm{S}\right)$ and the Mediterranean. Zoosystema, 29(2): 281-364.

Verhecken, A. 2011. The Cancellariidae of the PANGLAO Marine Biodiversity Project 2004 and the PANGLAO 2005 and AURORA 2007 deep sea cruises in the Philippines, with description of six new species (Neogastropoda, (ancellarioidea). Vita Malacologica, 9: 1-60.

Wiggers, F. \& Veitenheimer-Mendes, I.L. 2003. Gastrópodes atuais da plataforma continental externa e talude continental ao largo de Rio Grade, Rio Grande do Sul, Brasil. Revista Brasileira de Paleontologia, 6: 55-60.

Zamudio, K.R.; Kellner, A.; Serejo, C.; Britto, M.R.; Castro, C.B.; Buckup, P.A.; Pires, D.0.; Couri, M.; Kury, A.B.; Cardoso, I.A.; Monné, M.L.; Pombal-Jr., J.; Patiu, C.M.; Padula, V.; Pimenta, A.D.; Ventura, C.R.R.; Hajdu, E.; Zanol, J.; Bruna, E.M.; Fitzpatrick, J. \& Rocha, L.A. 2018. Lack of Science support fails Brazil. Science, 361(6409): 1322-1323. D0I 